\title{
Characterization of Maasai Goats in Extensive Production System in Northern Tanzania: Description of Phenotype, Reproductive and Productive Performance
}

\author{
Emil Hyera ${ }^{1}$, Athumani S. Nguluma ${ }^{1}$, Zabron C. Nziku ${ }^{2}$, Eligy J. M. Shirima ${ }^{3}$, Maria-Salome H. Mashingo ${ }^{4}$, \\ Raimundo N. B. Lobo ${ }^{5}$, Tesfaye Getachew ${ }^{6}$, Barbara Rischkowsky ${ }^{6}$ \& Aynalem Haile ${ }^{6}$ \\ ${ }^{1}$ Department of Research and Technology Development, Tanzania Livestock Research Institute, West \\ Kilimanjaro Centre, Sanya Juu, Kilimanjaro, Tanzania \\ ${ }^{2}$ Tanzania Livestock Research Institute, Tanga Centre, Tanga, Tanzania \\ ${ }^{3}$ TALIRI Headquarters, Tanzania Livestock Research Institute, Dodoma, Tanzania \\ ${ }^{4}$ Ministry of Livestock and Fisheries, Dodoma, Tanzania \\ ${ }^{5}$ Embrapa Caprinos e Ovinos, Sobral, CE, Brazil/CNPq PQ Scholarship \\ ${ }^{6}$ International Center for Agricultural Research in the Dry Areas (ICARDA), c/o ILRI, Addis Ababa, Ethiopia \\ Correspondence: Emil Hyera, Department of Research and Technology Development, Tanzania Livestock \\ Research Institute, West Kilimanjaro Centre, P.O. Box 147, Sanya Juu, Kilimanjaro, Tanzania. E-mail: \\ ehyera2004@yahoo.co.uk
}

Received: May 13, 2020

Accepted: September 27, 2020

Online Published: December 15, 2020

doi:10.5539/jas.v13n1p99

URL: https://doi.org/10.5539/jas.v13n1p99

\begin{abstract}
The study was designed to offer information on phenotype, reproductive and productive features of Maasai goats for amelioration in breeding programs utilizing these animals. Live measurements and qualitative traits were collected from 75 bucks and 165 does. A detailed survey was used to acquire information on reproductive and productive traits. Data were analyzed using descriptive statistics and General Linear Model procedures for age and sex as main effects. The results revealed that body weight, heart girth, chest depth, rump width, head length, head width and horn length differed $(p<0.05)$ among age groups. Body weight increased from young to old age and ranged from $25.83 \mathrm{~kg}$ to $30.34 \mathrm{~kg}$. Body length, heart girth, head length, head width and cannon bone length were significantly $(p<0.05)$ higher in bucks than does. Plain white was the foremost coat color manifested. Nearly, $76 \%$ of bucks and $78.2 \%$ of does had straight short hairs. Beards were in $80 \%$ of bucks and $9.1 \%$ of does. All goats had short and erect ears; whereas, more than $88 \%$ had horns, $48 \%$ of the horns were curved, $33.1 \%$ lateral and $18.1 \%$ straight. Almost $76 \%$ and $83.6 \%$ of the horns in bucks and does, respectively, were pointing backward. In both sexes, facial profile was mainly concave, back profile was straight and wattles were absent. Twinning rate, age at sexual maturity, age at first kidding, kidding interval and lactation length were averaged at $8.7 \%$, 11 months, 16.7 months, 7.7 months and 82.3 days; whereas, pre weaning kid survival rate was $77.1 \%$ and $79.9 \%$ for dry and rainy season, respectively. The strain was comparatively similar to most African indigenous goat populations. Thus, the strain can be utilized through selection for the traits preferred for the arid and semi-arid tropics.
\end{abstract}

Keywords: age at first kidding, live measurements, Maasai steppe zone, qualitative traits, survival rate

\section{Introduction}

Small ruminants particularly goats are one of the abundant assets and economical sources of animal protein that can be utilized to contribute to food security and income generation to the poor rural households in developing countries where poverty is a prevalent phenomenon. Goats play an important role in poverty alleviation and livelihoods of smallholder farmers in rural areas of these countries (Ng'ambi et al., 2013; Moela, 2014). They represent an efficient agricultural enterprise for farmers with limited land and other resources because they require little capital and constitute insignificant competition for arable land. Goats are relatively easy to manage, more prolific, have low metabolic requirements and quick maturity traits, can sustain themselves on the scarcity 
of drinking water, on sparse pasture forage resources and extreme environment where other animal species may perish (Silanikove, 2000; Moela, 2014).

In Tanzania, the national goat population is mainly composed of indigenous strains of goats which are well adapted to the arid and semi-arid tropical conditions (Njombe \& Msanga, 2008). Their superior adaptation to the tropical environment is contributed by their small body size, large ratio of the surface area relative to body weight, restricted subcutaneous fat deposition, selective browsing habit and efficient digestive system (Sherton, 1978; Silanikove, 2000). Besides, indigenous goats are resistant to manifold diseases infecting other animals in these areas (Sherton, 1978). Despite their superior adaptation to the local climatic conditions, most of the indigenous goats are seemed to have low productivity and their contribution to the national economy is below the potential. Goat milk contributes less than $1.5 \%$ to the total annual milk production in the country (Nell et al., 2014). The average carcass weight of Tanzanian indigenous goats is $12-15 \mathrm{~kg}$ (URT, 2015). This may be due to various factors such as poor nutrition, high prevalence of diseases and parasites and high mortality rates resulting in negative genetic progress and diminished benefits of high production performance (Masikati, 2010). Goat meat accounts for about $14 \%$ of the total red meat supply from ruminants in the country (Michael et al., 2018), which is low compared to the total red meat supply from ruminants in Ethiopia (16.8\%) (Ameha, 2008) and Nigeria (25\%) (Moela, 2014). The average annual meat consumption in the country are estimated at $9.6 \mathrm{~kg}$ per capita, which is lower than the average annual meat consumption of Uganda (11 kg per capita), Kenya (16.7 kg per capita), USA (124 kg per capita) and the global average annual meat consumption (38 kg per capita) (FAO, 2013; Tilahun et al., 2019).

Genetic improvement programs in goats have mainly focused on crossbreeding with exotic breeds regarded to be superior rather than selective breeding or utilizing the available variations within the local populations for improvement (Hiemstra et al., 2006). In crossbreeding, favorable breed combinations and complementarity are essential for hybrid vigor. However, for most indigenous goat populations, this strategy has been done without plans on how to maintain pure breeds for future use and without enough consideration of environmental conditions for production and farmers' preferences (Philipsson et al., 2011; Monau et al., 2018). This has usually resulted in wrong breeding objectives and animals with declined adaptation to the arid and semi-arid tropical climatic conditions (Philipsson et al., 2011). In the absence of baseline characterization information and appropriate breeding strategies, some breed populations and adapted traits they possess may decline significantly or disappear before their value is acknowledged and utilized (Gatew et al., 2015).

Information on phenotypic characteristics, reproductive and productive performance of some indigenous goat populations is still little (Gatew et al., 2015). There are many animal populations that are not specifically known to belong to certain particular breeds, which cause difficulty in assessing the diversity of animal genetic resources (FAO, 2011). Description of goat breeds is required for the knowledge of a valid diversity among breeds or populations comparison at local levels, on a national scale or worldwide. Characterization is a vital tool in animal selection and breeding and is essential for planning national domestic diversity conservation and improvement strategies (Dorji et al., 2006). Also, it permits the accurate classification of animals in different agro-ecological environments and it is a fundamental instrument in quantifying and mapping out an inventory of peculiar characteristics within a group of animals (Gatew et al., 2015). Moreover, baseline characterization provides crucial information for a comprehensive breeding policy for the species. In addition, it is the key to the development of proper strategies for sustainable utilization of the breeds in their natural habitats by small holder resource poor farmers majority of whom are located in marginal lands where low input production system is predominant (Manzi et al., 2011).

The majority of goats in Maasai steppe zone of Northern Tanzania are strains of indigenous breed of Small East African (SEA) goats. These animals play an important socio-economic role to the societies as they provide income, food, security against future uncertainties, wealth status, prestige and socio-cultural prosperity to the resource-poor farmers (Chenyambuga \& Lekule 2014; Gatew et al., 2015; Tilahun et al., 2019). Despite the extensive functions there is no information on phenotypic traits, reproductive and productive performance of these important genetic resources. Unavailability of information on the characteristics of these goats has resulted in poor efforts to fully utilize and conserve the breed strain. This survey was designed to study the phenotypic, reproductive and productive parameters of Maasai goats in their traditional production environment where they are predominantly raised. The findings generated in this study will help in improvement in breeding programs utilizing these potential animals for enhancing the livelihoods of smallholder farmers in rural areas. 


\section{Materials and Methods}

\subsection{Study Area and Research Design}

Cross-sectional survey was used to collect phenotypic characteristics of the animals sampled from three wards namely Masama Rundugai, Weruweru and KIA. The wards are located in the Maasai steppe agro-ecological zone in Hai district which has an altitude range of 900 to 1,873 meters above sea level, with an average annual rainfall of $521 \mathrm{~mm}$ and $23.3{ }^{\circ} \mathrm{C}$ of average annual temperature (URT, 2012). The study area receives annual rainfall in the range of 400 to $600 \mathrm{~mm}$ with bimodal pattern. The wards were purposively selected based on the criteria of large number of indigenous goats belonging to the breed of interest, agro-ecological context and absence of crossbreeding program. Furthermore, the studied goats were sampled from two villages in KIA ward and one village in each of Masama Rundugai and Weruweru wards. From each village a total of 40 randomly chosen households provided 60 goats that were randomly selected to make a total of 240 goats of both sexes ( 75 bucks and 165 does) for the survey centered on the agreed descriptors. Pregnant does, castrates and goats aged below one year were omitted from the sample population to represent the adult goat population and to increase precision for live measurement traits (FAO, 2012).

\subsection{Data Collection}

Data collection involved taking quantitative records such as body weight and linear measurements of mature, genetically unrelated animals in both sexes and describing their qualitative features. Due to lack of birth records of the animals, mature animals were identified and sampled through a combination of information provided by the farmers with information acquired by inspecting the dentition of the animals and those goats with one and above pair of permanent incisors were used in the study. Tailors measuring tape $(1.5$ meter and accuracy $0.5 \mathrm{~cm})$ and wooden measuring stick were used to obtain body linear measurements to the nearest centimeter $(\mathrm{cm})$. Animals were restrained in their standing position on a flat board so that the backbone is straight in both vertical and horizontal planes when taking linear measurements. The Hanson $50 \mathrm{Kg}$ capacity suspended spring balance, model No. 21, accuracy $200 \mathrm{~g}$ (H. Enterprises Mumbai, India) and a hanging fabric sling were used for taking body weight. Measurements of morphological traits and body weight were taken during morning before they were released for grazing to avoid the influence of feeding and watering on the size of animals (FAO, 2012). Measurements of body linear dimensions were carried out according to adopted Ethiopian Sheep and Goat Productivity Improvement Project (ESGPIP) guideline for estimation of weight and age of sheep and goat (ESGPIP, 2009). The following body linear records were taken (Figure 1):

(i) Body Length, measured diagonally as distance from the lateral tuberosity on scapula to the pin bone;

(ii) Heart Girth, measured as the circumference of the body around the chest just behind the front legs and withers;

(ii) Height at Withers, measured as the distance from a platform on which the animal stands to the withers;

(iv) Chest Depth, measured as the distance from the backbone at the shoulder (behind the scapular) to the flow of the sternum (considered to be the depth of brisket) proximately behind the fore legs;

(v) Rump Length, measured as the distance from hip bone (tuber coxa) to pin bone (tuber ischi);

(vi) Rump Width, measured as the distance between the two tuber coxae stuck between the greater trochanters of the femurs;

(vii) Head Length, measured as the distance from between the horn site to the tip of nose;

(viii) Head Width, the widest point of the head measured between the roots of the horns and the nuchal crest;

(ix) Horn Length, measured as the distance from the temple of the head (at the base of the horn) to the tip of the horn;

(x) Ear Length, measured as the distance from the point of attachment to the tip of the ear, and

(xi) Cannon bone length, measured as the length of the lower part of the fore leg extending from the hock to the fetlock.

Observation was made for qualitative traits such as sex, coat color type, coat color pattern, hair structure, presence or absence of horn, beard, wattles and ruff, horn shape, horn and ear orientation, facial and back profile using coded descriptors according to FAO (2012) animal production and health guidelines. Also, a detailed survey was carried out using a semi-structured questionnaire to collect indicative information on reproductive traits such as twinning percentage, age at sexual maturity, age at first kidding and kidding interval; and 
productive traits such as lactation length and pre weaning survivability. During interviews members of the household were asked to identify and recall events of their goats based on the above traits and the figures obtained were averaged to provide more realistic estimates of the traits (FAO, 2012).
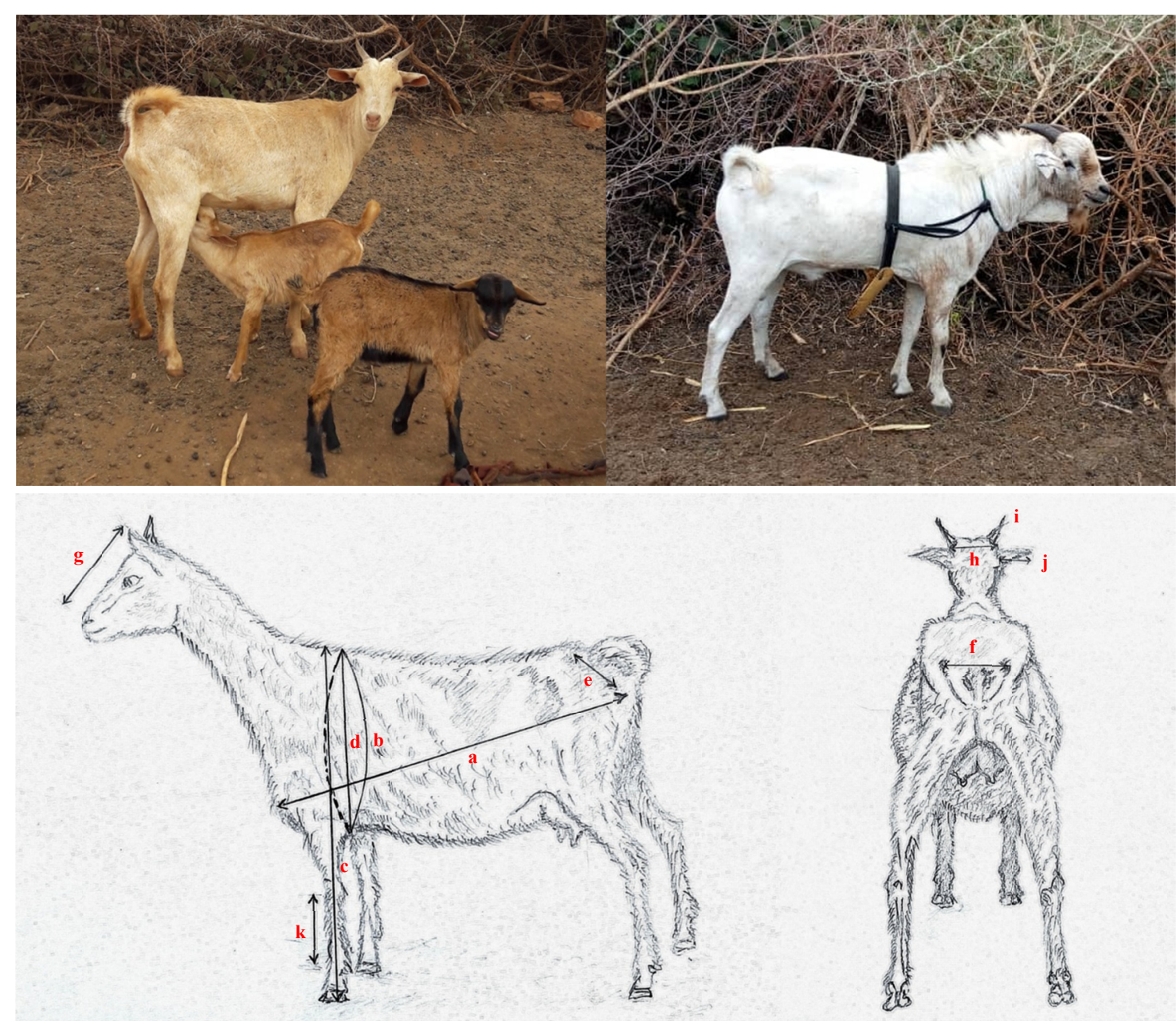

Figure 1. Physical appearances of the Maasai goats and graphic presentation of the morphometric analysis (a) Body Length, (b) Heart Girth, (c) Height at Withers, (d) Chest Depth, (e) Rump Length, (f) Rump Width, (g) Head Length, (h) Head Width, (i) Horn Length (j) Ear Length and (k) Cannon bone length

\subsection{Data Analysis}

Prior to the statistical analysis data of the live measurements was inspected using the scatterplot technique and the outlier values were cleaned out (Melaku et al., 2015). The effect of age and sex of animals on body weight and linear body measurements were analyzed using General Linear Model procedures (PROC GLM). Tukey-Kramer more conservative means comparison test was carried out to separate the least squares means and a $p<0.05$ represented the significant main effect. The statistical model for the observation was as follows:

$$
Y=\mu+A_{i}+B_{j}+e_{i j}
$$

Where, $Y_{i j k}=$ observed value for the trait measured, $\mu$ = overall least squares mean for the trait measured, $A_{i}=$ the effect of the $i^{\text {th }}$ age, $B_{j}=$ the effect of the $j^{\text {th }}$ sex of the animal and $e_{i j}=$ the residual error which is independently and evenly distributed with, mean $=$ zero and variance $=0^{2}$. Data on descriptive features of the animals were analyzed for frequency (qualitative traits), mean and standard error (reproductive and productive traits). 


\section{Results and Discussion}

\subsection{Variation in Live Measurement Traits}

Least squares means differed $(p<0.05)$ among age groups for body weight, heart girth, chest depth, rump width, head length, head width and horn length (Table 1). Body weight increased from young to old age and ranged from $25.83 \mathrm{~kg}$ to $30.34 \mathrm{~kg}$ for goats aged below two years and above three years, respectively. In previous indigenous goats' characterization results (Muluneh et al., 2016; Nguluma et al., 2016) body weight and conforming body linear measurements were significantly $(p<0.05)$ affected by age except ear length.

The range of body weight in this study is in line with the range of weight reported for other strains of SEA goats; from $22 \mathrm{~kg}$ to $29 \mathrm{~kg}$ for four SEA goat strains in Tanzania (Nguluma et al., 2016), $27.64 \mathrm{~kg}$ for SEA goats in Malawi (Karua \& Banda, 1993), $27 \mathrm{~kg}$ for Mubende goats in Uganda (Jimmy et al., 2010) and $28.1 \mathrm{~kg}$ for SEA goats in Central Tanzania (Chenyambuga et al., 2012). However, other researchers (Manzi et al., 2011; Msemwa \& Mbaga, 2018) reported slight higher average body weight than upper range observed in this study. Moreover, Jimmy et al. (2010) reported a lower body weight $(18.75 \mathrm{~kg})$ for another strain of SEA goats in Uganda. Body length was averaged at $57 \mathrm{~cm}$ and the values obtained for heart girth were in the range of 70-72 $\mathrm{cm}$ and were higher than those reported by Nguluma et al. (2016) for four strains of SEA goats. However, Manzi et al. (2011) reported higher values for body length and heart girth for SEA goats in Rwanda compared to the values obtained in this study. The variation in body weight and linear measurements reported for SEA goats in different studies could be caused by the effects of strain, production conditions or environment and sampling error among other factors. This indicates that there exists significant variation in body weight and dimension within the SEA goat breed. The variation can be used as a basis for selection within the indigenous goats for a sustainable improvement in productivity.

Table 1. Least Squares Means ( \pm standard error) for live measurement traits of Maasai goat according to class age

\begin{tabular}{llll}
\hline Age group & 1 to 2 years & 2 to 3 years & Above 3 years \\
\hline Body Weight $(\mathrm{kg})$ & $25.83 \pm 0.33^{\mathrm{c}}$ & $28.20 \pm 0.47^{\mathrm{b}}$ & $30.34 \pm 0.47^{\mathrm{a}}$ \\
Body Length (cm) & $57.04 \pm 0.31$ & $57.31 \pm 0.27$ & $57.36 \pm 0.26$ \\
Heart Girth $(\mathrm{cm})$ & $70.19 \pm 0.49^{\mathrm{b}}$ & $72.13 \pm 0.46^{\mathrm{a}}$ & $72.29 \pm 0.56^{\mathrm{a}}$ \\
Height at Withers (cm) & $61.83 \pm 0.42$ & $62.43 \pm 0.40$ & $63.19 \pm 0.48$ \\
Chest Depth (cm) & $27.11 \pm 0.27^{\mathrm{b}}$ & $28.89 \pm 0.31^{\mathrm{a}}$ & $29.05 \pm 0.25^{\mathrm{a}}$ \\
Rump Length (cm) & $14.27 \pm 0.26$ & $15.03 \pm 0.25$ & $15.07 \pm 0.30$ \\
Rump Width (cm) & $12.99 \pm 0.25^{\mathrm{b}}$ & $13.35 \pm 0.27^{\mathrm{ab}}$ & $14.02 \pm 0.31^{\mathrm{a}}$ \\
Head Length (cm) & $17.13 \pm 0.17^{\mathrm{b}}$ & $17.43 \pm 0.19^{\mathrm{b}}$ & $18.09 \pm 0.16^{\mathrm{a}}$ \\
Head Width (cm) & $7.81 \pm 0.12^{\mathrm{b}}$ & $7.78 \pm 0.14^{\mathrm{b}}$ & $9.11 \pm 0.12^{\mathrm{a}}$ \\
Horn Length (cm) & $9.29 \pm 0.28^{\mathrm{b}}$ & $9.88 \pm 0.27^{\mathrm{ab}}$ & $10.09 \pm 0.29^{\mathrm{a}}$ \\
Ear Length $(\mathrm{cm})$ & $12.31 \pm 0.18$ & $12.32 \pm 0.20$ & $12.56 \pm 0.17$ \\
Fore cannon bone length $(\mathrm{cm})$ & $13.01 \pm 0.12$ & $13.08 \pm 0.10$ & $13.33 \pm 0.10$ \\
\hline
\end{tabular}

Note. Within row, means with different letters are significantly different by Tukey test $(p<0.05)$.

Body length, heart girth, head length, head width and cannon bone length were significantly $(p<0.05)$ higher in bucks than in does, whereas other live measurement traits were not affected by sex (Table 2). In another study for SEA goats (Nguluma et al., 2016) bucks were superior to does in all conforming live measurement traits except ear length. Besides, Msemwa and Mbaga (2018) observed that linear measurements such as body length, heart girth, withers height and rump height were significant $(p<0.05)$ higher in bucks than in does similar to the study of Madubi et al. (2000) for SEA strain. In each sex, most of the live measurement traits were relatively higher than values reported by Chenyambuga et al. (2012) and Nguluma et al. (2016) for strains of SEA goats, but were lower than the findings of Msemwa and Mbaga (2018).

It is a normal practice to refer to all the indigenous goats in Tanzania and in East Africa as SEA goats implying that they all belong to one breed. The variations that have been observed in most of the indigenous goats characterization studies indicate that inventory of local breeds in Tanzania and African countries is not exhaustive similar to what has been reported by FAO (2011). For that reason, exhaustive characterization programs helps to provide a better understanding of the potential of indigenous goat populations in Tanzania and allow for sustainable improvement and utilization. 
Table 2. Least squares means ( \pm standard error) for live measurement traits of Maasai goat according to the sex

\begin{tabular}{lll}
\hline Sex & Bucks & Does \\
\hline Body Weight $(\mathrm{kg})$ & $28.62 \pm 0.66$ & $27.71 \pm 0.43$ \\
Body Length $(\mathrm{cm})$ & $58.61 \pm 0.38^{\mathrm{a}}$ & $55.87 \pm 0.58^{\mathrm{b}}$ \\
Heart Girth $(\mathrm{cm})$ & $72.96 \pm 0.51^{\mathrm{a}}$ & $70.11 \pm 0.34^{\mathrm{b}}$ \\
Height at Withers $(\mathrm{cm})$ & $62.91 \pm 0.44$ & $62.06 \pm 0.29$ \\
Chest Depth $(\mathrm{cm})$ & $28.60 \pm 0.29$ & $28.10 \pm 0.19$ \\
Rump Length $(\mathrm{cm})$ & $15.01 \pm 0.28$ & $14.58 \pm 0.18$ \\
Rump Width $(\mathrm{cm})$ & $13.78 \pm 0.19$ & $13.12 \pm 0.28$ \\
Head Length $(\mathrm{cm})$ & $17.79 \pm 0.17^{\mathrm{a}}$ & $17.31 \pm 0.12^{\mathrm{b}}$ \\
Head Width $(\mathrm{cm})$ & $8.54 \pm 0.13^{\mathrm{a}}$ & $7.94 \pm 0.08^{\mathrm{b}}$ \\
Horn Length $(\mathrm{cm})$ & $9.94 \pm 0.30$ & $9.56 \pm 0.18$ \\
Ear Length $(\mathrm{cm})$ & $12.26 \pm 0.19$ & $12.53 \pm 0.12$ \\
Fore cannon bone length $(\mathrm{cm})$ & $13.46 \pm 0.11^{\mathrm{a}}$ & $12.82 \pm 0.07^{\mathrm{b}}$ \\
\hline
\end{tabular}

Note. Within row, means with different letters are significantly different by Tukey test $(p<0.05)$.

\subsection{Qualitative Description}

Plain white is the most prominent coat color observed in this study (Figure 1). Although the appearance of several coat colors was small in a population, the studied goats demonstrated a wide range of coat colors. Similar findings have been reported by Madubi et al. (2000) and Nguluma et al. (2016) for SEA goat strains from various areas in Tanzania. However, Msanga et al. (2001) reported colors such as brown, black, pied or spotted black and white as the most common coat colors for SEA goats in central Tanzania. Coat color is useful in protecting the skin against solar shortwave radiation in tropical conditions (Monau et al., 2018). Farmers' preference for white coat color is associated with the attached social value, which makes it to be one of their selection criteria, hence the variation. Since long the predominance of certain colors in a herd has been due to natural selection, individual preferences, ceremonial and ritual use (Finch \& Western, 1977). Normally, coat color is not considered an economically important trait because it has no direct impact on productivity. However, views and choices of the farmers and their preferences should be considered when designing a Community Based Breeding Program because coat color has big influence on marketing decisions and culling of animals which ultimately affect the genetic structure of the population.

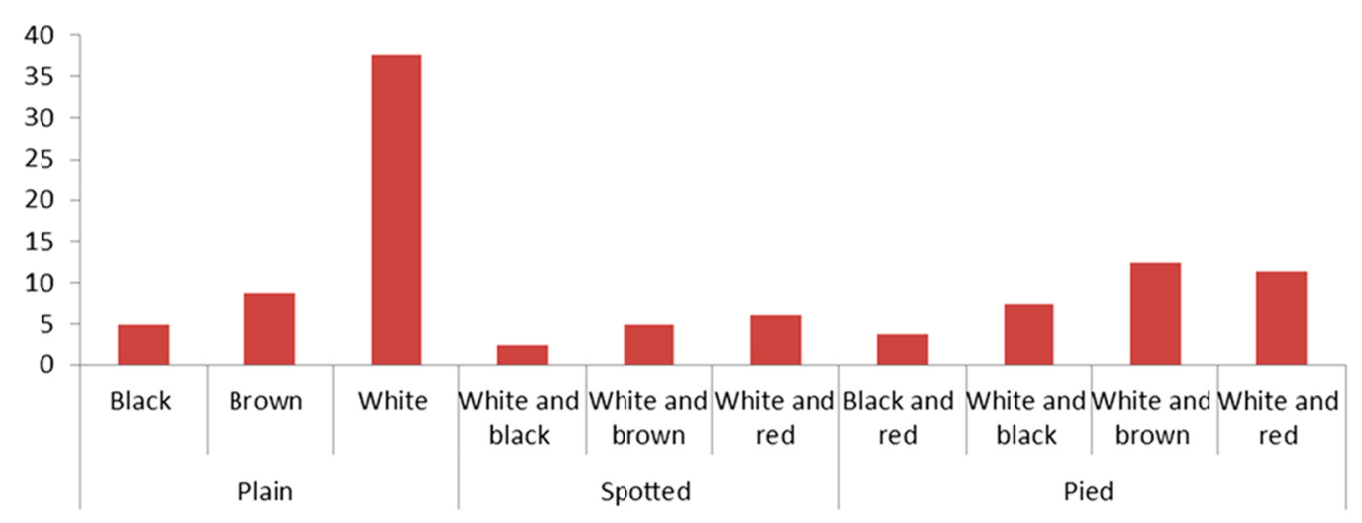

Figure 1. Coat color type and pattern for Maasai goats

The majority of the goats had straight short hairs with beards present in $80 \%$ of bucks and $9.1 \%$ of does (Table 3 ). Ear was characteristically short and erect oriented and horns were present in more than $88 \%$ of the studied goat population and about $48 \%$ of the horns were curved, $33.1 \%$ were lateral and $18.1 \%$ were straight. A proportion of $76 \%$ and $83.6 \%$ of the horns in bucks and does, respectively, were pointing backward In both sexes, facial profile was mainly concave, back profile was characteristically straight and wattles were absent. Possession of the above phenotypic qualitative traits in indigenous goats also has been reported for SEA goat strains in Northern and 
Lake Zones of Tanzania (Nguluma et al., 2016; Msemwa \& Mbaga, 2018), for SEA goats in Rwanda (Manzi et al., 2011), for Tswana goats in Botswana (Katogole et al., 1996; Monau et al., 2018), for Beni arrous goats in Morocco (Hilal et al., 2014) and for indigenous goat populations from various ecological zones of Ethiopia (Muluneh et al., 2016; Gatew et al., 2017; Gebreyowhens \& Kumar, 2017; Tilahun et al., 2019). Appearance of beards is influenced by sex (sexual dimorphism) and does displaying the feature might have more secretion of androgens, a male hormone (Adedeji et al., 2006; Hilal et al., 2014). The trait is believed to be associated with superior reproductive parameters such as fertility, conception and prolificacy. Further studies are required to establish the influence of the trait on adaptation, performance and productivity so that it can be included among the selection criteria in genetic improvement programs for indigenous goat populations (Monau et al., 2018). Phenotypic features such as coat color, ear size and orientation, horn shape and orientation can be used for identification. In Tanzania in particular coat color has been used along with ethnicity of livestock keepers as a way of identifying and naming animal populations without regard to whether the differences are genetic and distinct enough for a population to be considered unique from others. This causes a lot of intermixing and confusion in naming of goat populations and calls for a more detailed characterization to molecular level.

Table 3. Occurrence (\%) of qualitative traits in Maasai goat population

\begin{tabular}{|c|c|c|c|c|}
\hline Variable & Category & Bucks & Does & Total \\
\hline \multirow{2}{*}{ Hair size } & Medium & 24 & 21.8 & 22.5 \\
\hline & Short & 76 & 78.2 & 77.5 \\
\hline \multirow{2}{*}{ Beard } & Present & 80 & 9.1 & 31.2 \\
\hline & Absent & 20 & 90.9 & 68.8 \\
\hline Ear orientation & Erect & 100 & 100 & 100 \\
\hline \multirow{2}{*}{ Horn } & Present & 88 & 89.1 & 88.8 \\
\hline & Absent & 12 & 10.9 & 11.2 \\
\hline \multirow{3}{*}{ Horn shape } & Curved & 52 & 45.5 & 48.8 \\
\hline & Lateral & 28 & 38.2 & 33.1 \\
\hline & Straight & 20 & 16.3 & 18.1 \\
\hline \multirow{2}{*}{ Horn orientation } & Backward & 76 & 83.6 & 93 \\
\hline & Upward & 8 & 5.5 & 7 \\
\hline \multirow{2}{*}{ Facial profile } & Straight & 44 & 45.5 & 44.8 \\
\hline & Concave & 56 & 54.5 & 55.2 \\
\hline \multirow{2}{*}{ Wattle } & Present & 0 & 0 & 0 \\
\hline & Absent & 100 & 100 & 100 \\
\hline Back profile & Straight & 100 & 100 & 100 \\
\hline
\end{tabular}

\subsection{Reproductive and Productive Performance}

The twinning rate was calculated as $8.7 \%$, bucks and does reached sexual maturity at around 11 months of age and does were reported to have their first kids when they are 16.7 months old (Table 4). Kidding interval was 7.7 months, lactation length was 82.3 days ( 2.9 months) and pre weaning kid survival rate was $77.1 \%$ and $79.9 \%$ for dry and rainy season, respectively. The twinning rate obtained in the current study is lower than the range of 18 to $36 \%$ estimated for Arsi-Bale goat population in Ethiopia (Tatek et al., 2004; Tsedeke, 2007; Dadi et al., 2008). Twinning for SEA goats vary greatly with some strains having values ranging from 5-15\% (Ssewannyama et al., 2004) and others reaching 30\% and triplets occuring rarely at 2\% (Sacker \& Trail, 1966; Nsubuga, 1994).

In this study, the values for age at sexual maturity between males and females were higher than those values reported by Wendimu et al. (2018) for indigenous goats in Ethiopia. The age at first kidding concurs with the range of 15.9 to 16.6 months reported by FAO (2002) in the arid and semi-arid areas of sub-Sahara African countries. Similarly, age at first kidding was reported to be 14.2 and 16.8 months for two SEA goat strains in different localities in Central Tanzania (Chenyambuga et al., 2012). Lower age at first kidding of 12.4 and 13.6 months were reported in Ethiopia (Tsegaye, 2009), 14.6 months for Red Sokoto goats in Nigeria and 15.6 for Malawi goats (Dereje et al., 2015). The average kidding interval of 7.7 months conforms to that reported for SEA goats in Kongwa (7.6 months) but slightly lower than that of SEA goats in Iramba (8.2 months) both in central Tanzania (Chenyambuga et al., 2012). Also, Mtenga et al. (1994) reported a higher average kidding interval of 12 
months in SEA goats. Variation in these reproductive traits is a function of the breed/strain, feeding and the total production conditions. Farmers usually prefer high kidding rate, but it can also be the reason for high pre-weaning mortality especially if kidding occurs during the season when there is acute shortage of feeds for the animals. For kidding to have impact on the productivity of the farm, mating should be planned so that kidding might occur during plenty feed availability. This can be done through synchronization followed by insemination of the does so that kidding occurs at a pre-planned time.

The value for lactation length obtained in this study was higher than values reported by Berhane and Eik (2006) for indigenous goats in Ethiopia. However, other studies (Lemma et al., 2003; Hagos et al., 2017) reported higher results for lactation length compared to the current study. The present results on pre-weaning kid survival indicate that mortality was in lower end of the range of 20-40\% reported in URT (2015) for indigenous goat population in Tanzania. Pre-weaning kid survival was higher by $2.8 \%$ in rainy season compared to the dry season, suggesting a very small difference in mortality rates between the two seasons. This might be because rain water caused temporal flooded areas in the lowlands that reduced the availability of pasture forage resources, which might resulted to nutritional stress and loss of does' body weight, abortions, and weak kids due to lighter birth weight, hence diminished rate of kid survival. Several authors reported results for pre weaning mortality rate ranging from higher to lower values in indigenous goat populations (Tatek et al., 2004; Tsedeke, 2007; Getahun, 2008; Girma et al., 2011; Assen \& Aklilu, 2012; Dereje et al., 2015).

Reproductive and productive performance parameters are classified as the most economically important traits of livestock (Zewdie \& Welday, 2015). These traits vary greatly with several important factors of goat farming enterprise such as breed of the goat, production conditions, kidding season, health care, nutrition and feeding scheme. Optimum goat farming techniques depend on high consideration of the above factors for the uptake of successful and profitable goat production. When animal health care is considered ideal, traits such as age at sexual maturity, gestation length, age at first kidding, kidding interval, lactation length and postpartum estrus significantly vary with season (Joshi et al., 2018). Basing on the tropical climate of Tanzania, doe goats conceived during short rainy season have quick and proper growth and development of fetus due to great quantity of nutritious forage and fodder plant species. Also, kidding occurs during long rainy season when pre weaning kid survival is not likely to be affected by shortage of feeds, shorter lactation lengths are desired as they imply quick return to reproduction cycle of the animals, reduced kidding interval and hence more kids that grow fast to attain earlier sexual maturity per period of time. For lucrative scale goat farming, management factors influencing reproductive and productive traits should be the great consideration because poor reproductive and productive performance is the foremost indicator of diminished farm productivity (Mukasa-Mugerwa et al., 2002; Joshi et al., 2018).

Table 4. Reproductive and productive performance of Maasai goat

\begin{tabular}{lll}
\hline Trait & Mean & Standard Error \\
\hline Twining rate (\%) & 8.70 & 1.56 \\
Age at sexual maturity for males (months) & 11.87 & 0.32 \\
Age at sexual maturity for females (months) & 11.70 & 0.29 \\
Age at first kidding for does (months) & 16.70 & 0.36 \\
Kidding interval (months) & 7.72 & 0.30 \\
Lactation length (days) & 82.32 & 1.30 \\
Pre weaning kid survival in dry season (\%) & 77.19 & 2.09 \\
Pre weaning kid survival in rainy season (\%) & 79.91 & 2.08 \\
\hline
\end{tabular}

\section{Conclusion and Recommendation}

The Maasai goats are relatively similar to other SEA goat strains in live measurements, reproductive and productive traits as most of the values are within the ranges reported in the literature. Also, the strain has traits similar to those of most African indigenous goat populations even though there were some variations ascertained. Therefore, the strain can be exploited through selection for the traits preferred for the arid and semi-arid tropical environments. 


\section{Acknowledgements}

This research work was supported by M-BoSs project (Embrapa) on goat upscaling in Ethiopia and Tanzania. Authors greatly acknowledge the financial support provided by the International Center for Agricultural Research in the Dry Areas (ICARDA). The authors also would like to acknowledge the staff of Tanzania Livestock Research Institute (TALIRI)-West Kilimanjaro Centre and the extension agents of Hai district who participated in the study. Farmers who participated in the interview are highly acknowledged.

\section{References}

Adedeji, T. A., Ojedapo L. O., \& Adedeji, O. S. (2006). Characterization of traditionally reared West African Dwarf goats (WAD) in the derived savannah zone of Nigeria. Journal of Animal and Veterinary Advances, 5, 686-688.

Ameha, S. (2008). Sheep and goat meat characteristics and quality. In A. Yami \& R. C. Merkel (Eds.), Sheep and goat production handbook for Ethiopia (pp. 323-328). Ethiopian Sheep and Goats Productivity Improvement Program (ESGPIP), USAID, Addis Ababa, Ethiopia.

Assen, E., \& Aklilu, H. (2012). Sheep and goat production and utilization in different agro-ecological zones in Tigray, Ethiopia. Livestock Research for Rural Development, 24(16). Retrieved from http://www.lrrd.org/ lrrd24/1/asse24016.htm

Berhane, G., \& Eik, L. O. (2006). Effect of vetch (Vicia sativa) hay supplementation to Begait and Abergelle goats in Northern Ethiopia II. Reproduction and growth rate, Small Ruminant Research, 64, 233-240. https://doi.org/10.1016/j.smallrumres.2005.04.020

Chenyambuga, S. W., \& Lekule, F. P. (2014). Breed preference and breeding practices for goats in agro-pastoral communities of semi-arid and sub-humid areas in Tanzania Livestock Research for Rural Development, 26(117). Retrieved from http://www.lrrd.org//rrd26/6/chen26117.html

Chenyambuga, S. W., Komwihangilo, D. M., \& Jackson, M. (2012). Production performance and desirable traits of Small East African goats in semi-arid areas of Central Tanzania. Livestock Research for Rural Development, 24(118). Retrieved from http://www.lrrd.org/lrrd24/7/chen24118.htm

Dadi, H., Duguma, G., Shelima, B., Fayera, T., Tadesse, M., Woldu, T., \& Tucho, T. A. (2008). Non-genetic factors influencing post-weaning growth and reproductive performances of Arsi-Bale goats. Livestock Research for Rural Development, 20(114). Retrieved from http://www.lrrd.org//rrd20/7/dadi20114.htm

Dereje, T., Mengistu, U., Getachew, A., \& Yoseph, M. (2015). A review of productive and reproductive characteristics of indigenous goats in Ethiopia. Livestock Research for Rural Development, 27(2). Retrieved from http://www. lrrd.org/lrrd27/2/dere27034.html

Dorji, T. G., Tshering, T., Wangchuk, J. E., Rege, O., \& Hannote, O. (2006). Indigenous Sheep Genetic Resources and Management in Bhutan. International Journal of Agriculture and Rural Development, 5, $2-45$.

ESGPIP (Ethiopian Sheep and Goat Productivity Improvement Project). (2009). Estimation of weight and age of sheep and goats. Technical Bulletin No. 23. ESGPIP, Ethiopia. Retrieved from http://www.esgpip.org/PDF/ Technical\%20bulletin\%20No.23.pdf

FAO (Food and Agriculture Organization of the United Nations). (2002). Cattle and Small Ruminant Production Systems in sub-Saharan Africa-A Systematic Review. In M. J. Otte, \& P. Chilonda (Eds.), Livestock Information Sector Analysis and Policy Branch. FAO, Rome, Italy.

FAO (Food and Agriculture Organization of the United Nations). (2011). Draft Guidelines on Phenotypic Characterization of Animal Genetic Resources. Report of the Commission on Genetic Resources for Food and Agriculture, July 18-22, 2011, Rome, Italy.

FAO (Food and Agriculture Organization of the United Nations). (2012). Phenotypic characterization of animal genetic resources. FAO Animal Production and Health Guidelines No. 11. Rome, Italy.

FAO (Food and Agriculture Organization of the United Nations). (2013). Current Worldwide Annual Meat Consumption per Capita. Livestock and Fish Primary Equivalent. Retrieved from http://faostat.fao.org/site/ 610/DesktopDefault.aspx?PageID=610\#ancor

Finch, V. A., \& Western, D. (1977). Cattle colors in pastoral herds: Natural selection or social preference? Ecology, 58, 1384-1392. https://doi.org/10.2307/1935090 
Gatew, H., Hassen, H., Kebede, H., Haile, A., Lobo, R. N. B., Yetayew, A., \& Rischkowsky, B. (2017). Husbandry practices and phenotypic characteristics of indigenous goat populations in Ethiopia. African Journal of Agricultural Research, 12(36), 2729-2741. https://doi.org/10.5897/AJAR2016.11282

Gatew, H., Hassen, H., Kebede, K., Haile, A., Lobo, R. N. B., Yetayew, A., \& Rischkowsky, B. (2015). Characterization of indigenous goat populations in selected areas of Ethiopia, American-Eurasian Journal of Scientific Research, 10(5), 287-298.

Gebreyowhens, W. R., \& Kumar, R. (2017). Phenotypic characterization of indigenous Maefur goat population in Tigray, Northern Ethiopia. International Journal of Biodiversity and Conservation, 9(5), 130-145. https://doi.org/10.5897/IJBC2016.1057

Getahun, L. (2008). Productive and Economic performance of Small Ruminant Production in Production System of the Highlands of Ethiopia (Doctoral dissertation, University of Hohenheim, Stuttgart-Hoheinheim, Germany).

Girma, D., Misgana, D., \& Feyisa, H. (2011). Effect of different factors on mortality rate of Arsi- Bale kids in Mid Rift Valley of Ethiopia. Global Veterinaria, 6(1), 56-60.

Hagos, A., Gizaw, S., \& Urge, M. (2017). Milk production performance of Begait goat under semi intensive and extensive management in Western Tigray, North Ethiopia. Livestock Research for Rural Development, 29(240). Retrieved from http://www. lrrd.org/lrrd29/12/hags29240.html

Hiemstra, S. J., Drucker, A. G., Tvedt, M. W., Louwaars, N., Oldenbroek, J. K., Awgichew, K., ... da Silva Mariante, A. (2006). Exchange, Use and Conservation of Animal Genetic Resources, Policy and Regulatory Options (CGN Report 2006/06).

Hilal, B., El Otmani, S., Chentouf, M., \& Boujenane, I. (2014). Morphological characterization of the local goat population "Beni Arrous". In M. Chentouf, A. López-Francos, M. Bengoumi, \& D. Gabiña (Eds.), Technology creation and transfer in small ruminants: Roles of research, development services and farmer associations (pp. 433-437). Zaragoza: CIHEAM/INRAM/FAO.

Jimmy, S., David, M., Donald, K. R., \& Dennis, M. (2010). Variability in Body Morphometric Measurements and Their Application in Predicting Live Body Weight of Mubende and Small East African Goat Breeds in Uganda. Middle-East Journal of Scientific Research, 5, 98-105.

Joshi, A., Kalauni, D., \& Bhattarai, N. (2018). Factors Affecting Productive and Reproductive Traits of Indigenous Goats in Nepal. Archives of Veterinary Science and Medicine, 1(1), 19-27. https://doi.org/ 10.26502/avsm.003

Karua, S. K., \& Banda, J. W. (1993). The performance of Small East African goats and their Saanen crosses in Malawi. Retrieved from http://www.fao.org/wairdocs/ilri/x5472b/x5472n0i.htm

Katongole, J. B. D., Sebolai, B., \& Madimabe, M. J. (1996). Morphological characterization of the Tswana goat, In S. H. B. Lebbie \& E. Kagwini (Eds.), Proceedings of the Third Biennial Conference of the African Small Ruminant Research Network, December 5-9, 1994, UICC, Kampala, Uganda (pp. 43-47). ILRI, Nairobi, Kenya.

Lemma, F., Lemma, A., Nega, T., \& Tesfaye, A. (2003). Effect of different legume supplementation on milk production performance of Borana Goats. In J. Yilma, \& G. Getachew (Eds.), Proceedings of the 10th Annual conference of the Ethiopian Society of Animal Production, August 22-24, 2002, Addis Ababa, Ethiopia (pp. 363-365).

Madubi, M. A., Kifaro, G. C., \& Petersen, P. H. (2000). Phenotypic characterization of three strains of indigenous goats in Tanzania. Animal Genetics Research, 28, 41-51. https://doi.org/10.1017/S101423390 0001358

Manzi, M., Rutagwenda, T., Kanuya, N., \& Chatikobo, P. (2011). Phenotypic Characterization of Goats Raised under Traditional Husbandry Systems in Bugesera and Nyagatare Districts of Rwanda. Journal of Animal and Veterinary Advances, 10, 3297-3302.

Masikati, P. (2010). Improving the water productivity of integrated crop-livestock systems in the semi-arid tropics of Zimbabwe: An ex-ante analysis using simulation modeling. Retrieved from http://www.zef.de/ fileadmin/webfiles/downloads/zefc_ecology_development/eds_78_masikati_text.pdf

Melaku, S., Kidane, A., \& Haile, A. (2015). Characterization of the goat population and breeding practices of goat owners. Mitigating Land Degradation and Improving Livelihoods-An integrated watershed approach 
(pp. 233-251). New York, United States: Taylor \& Francis (Routledge). https://doi.org/10.4324/9781315 754444-27

Michael, S., Mbwambo, N., Mruttu, H., Dotto, M., Ndomba, C., da Silva, M., ... Gebru, G. (2018). Tanzania livestock master plan (pp. $\mathrm{Xx}+82$ ). Nairobi, Kenya: International Livestock Research Institute.

Moela, A. K. (2014). Assessment of the relationship between body weight and body measurements in indigenous goats using path analysis (pp. 1-56, Master's thesis, University of Limpopo, South Africa).

Monau, P. I., Visser, C., Nsoso, S. J., \& van Marle-Köster, E. (2018). Phenotypic and genetic characterization of indigenous Tswana goats. South African Journal of Animal Science, 48(5), 925-934. https://doi.org/10.4314/ sajas.v48i5.12

Msanga, Y. N., Mbaga, S. H., \& Msechu, J. K. (2001). Farm Animals, Breeds and Strains of Tanzania. Proceedings of SUA-MU ENRECA Project Workshop on Farm Animals Genetic Resources (pp. 36-49). Morogoro, Tanzania.

Msemwa, J. L., \& Mbaga, S. H. (2018). Physical Characteristics and Selection Criteria of Pare White Goats in Kilimanjaro and Manyara districts, Tanzania. Tanzania Jourmal of Agricultural Science, 17(2), 46-53.

Mtenga, L. A., Kifaro, G. C., \& Berhanu, B. (1994). Studies on factors affecting reproductive performance and mortality rates of small East African goats and their crosses In S. H. B. Lebbie, B. Rey, \& E. K. Irungu (Eds.), Small Ruminant Research and Development in Africa: Proceedings of the 2nd Biennial Conference of the African Small Ruminant Research Network, December 7-11, 1992, AICC, Arusha, Tanzania (pp. 69-74). International Livestock Centre for Africa, Addis Ababa, Ethiopia.

Mukasa-Mugerwa, E., Anindo, D., Sovani, S., Lahlou-Kassi, A., Tebely, S., Rege, J. E. O., \& Baker, R. L. (2002). Reproductive performance and productivity of Menz and Horro sheep lambing in the wet and dry seasons in the highlands of Ethiopia. Small Ruminant Research, 45, 261-271. https://doi.org/10.1016/S0921-4488(02) 00155-4

Muluneh, B., Kebede, K., \& Mekasha, Y. (2016). Phenotypic Characterization of Indigenous Goat Types in West Gojjam Zone, Amhara National Regional State, Ethiopia. Journal of Biology, Agriculture and Healthcare, $6(6), 54-64$.

Nell, A., Schiere, H., \& Bol, S. (2014). Quick scan: Dairy sector Tanzania (p. 1-51). A Report Written at the Request of the Dutch Ministry of Economic Affairs. Department of European Agricultural Policy and Food Security, DG Agro.

Ng'ambi, J. W., Alabi, O. J., \& Norris, D. (2013). Role of goats in food security, poverty alleviation and prosperity with special reference to Sub-Saharan Africa: A review. Indian Journal of Animal Research, 47(1), 1-9.

Nguluma, A. S., Msalya, G., \& Chenyambuga, S. W. (2016). Phenotypic variation among four populations of small East African goats of Tanzania. Livestock Research for Rural Development, 28(136). Retrieved from http://www.lrrd.org/lrrd28/8/ngul28136.html

Njombe, A. P., \& Msanga, Y. N. (2008). Livestock and Dairy Industry Development in Tanzania. Department of Livestock Production and Marketing Infrastructure Development, Ministry of Livestock Development, Tanzania.

Nsubuga, H. S. K. (1994). Small ruminants: Goats and sheep in Uganda. In S. H. B. Lebbie \& E. Kagwini (Eds.), Small Ruminant Research and Development in Africa: Proceedings of the Third Biennial Conference of the African Small Ruminant Research Network, December 5-9, 1994, UICC, Kampala, Uganda (p. 326). International Livestock Research Institute, Nairobi, Kenya.

Philipsson, J., Rege, J. E. O., Zonabend, E., \& Okeyo, A. M. (2011). Sustainable breeding programmes for tropical farming systems, In J. M. Ojango, B. Malmfors, \& A. M. Okeyo (Eds.), Animal Genetics Training Resource (Version 3). International Livestock Research Institute, Nairobi, Kenya, and Swedish University of Agricultural Sciences, Uppsala, Sweden.

Sacker, G. D., \& Trail, J. C. M. (1966). Production characteristics of a herd of East African Mubende goats. Tropical Agriculture, 43, 43-51.

Sherton, M. (1978). Reproduction and Breeding of Goats. Journal of Dairy Science, 61, 994-1010. https://doi.org/10.3168/jds.S0022-0302(78)83680-7 
Silanikove, N. (2000). The physiological basis of adaptation in goats to harsh environments. Small Ruminant Research, 35, 181-193. https://doi.org/10.1016/S0921-4488(99)00096-6

Ssewanyana, E., Oluka, J., \& Masaba, J. K. (2004). Growth and performance of indigenous crossbred goats. Uganda Journal of Agricultural Science, 9, 537-542.

Tatek, W., Hailu, D., Mieso, G., \& Dadi, G. (2004). Productivity of Arsi-Bale goat types under farmers' management condition: A case of Arsi Negelle. Proceedings of the 13th Annual Conference of the Ethiopian Society of Animal Production, Addis Ababa, Ethiopia (pp. 67-71).

Tilahun, H., Haile, A., \& Seid, A. (2019). Phenotypic Characterization of Indigenous Goats in North Shewa Zone, Amhara Region, Ethiopia. International Journal of Research Studies in Agricultural Sciences, 5(7), 44-55. https://doi.org/10.20431/2454-6224.0507005

Tsedeke, K. (2007). Production and Marketing of Sheep and Goats in Alaba, SNNPR (Master's Thesis, Hawassa University, Hawassa, Ethiopia).

Tsegaye, T. (2009). Characterization of goat production systems and on-farm evaluation of the growth performance of grazing goats supplemented with different protein sources in Metema woreda, Amhara region, Ethiopia (p. 69, Master's Thesis, Haramaya University, Haramaya, Ethiopia).

URT (United Republic of Tanzania). (2012). Tanzania Meteorological Agency, Kilimanjaro International Airport Station, Kilimanjaro.

URT (United Republic of Tanzania). (2015). Livestock Modernization Initiative. Ministry of Livestock and Fisheries Development, Government Printer, Dar es Salaam.

Wendimu, B., Oumer, S., \& Habtamu, A. (2018). Characterization of the indigenous goat production system in Asossa zone, Benishangul Gumuz region, Ethiopia. African Journal of Food, Agriculture, Nutrition and Development, 18(3), 13558-13571. https://doi.org/10.18697/ajfand.83.17260

Zewdie, B., \& Welday, K. (2015). Reproductive Performance and Breeding Strategies for Genetic Improvement of Goat in Ethiopia: A Review. Greener Journal of Agricultural Sciences, 5(1), 23-33. http://doi.org/ 10.15580/GJAS.2015.1.080614317

\section{Copyrights}

Copyright for this article is retained by the author(s), with first publication rights granted to the journal.

This is an open-access article distributed under the terms and conditions of the Creative Commons Attribution license (http://creativecommons.org/licenses/by/4.0/). 